\title{
Plasma Histamine Levels During the First Week of Life
}

\author{
L. V. COOPER, D. R. HARVEY, ${ }^{\star}$ and J. A. DAVIS $†$ \\ From the Nuffield Neonatal Research Unit, Institute of Child Health, Hammersmith Hospital, London
}

Babies asphyxiated at birth and premature babies who develop the idiopathic respiratory distress syndrome of the newborn excrete larger than normal quantities of histamine in the urine during the first 24 hours of life (Cooper and Davis, 1968). Since histamine could play a part in the genesis of the respiratory distress syndrome it seemed important to establish normal plasma levels for the newborn.

There is considerable evidence to support the view that histamine in the blood is carried in the eosinophil and basophil leucocytes (Graham et al., 1955; Mitchell and Cass, 1959). If the action of the eosinophils is to counter that of histamine, as has been shown to be the case in race-horses (Archer, 1963), newborn babies with an 'eosinophil rash' (urticaria neonatorum, erythema toxicum neonatorum) might be expected to have some abnormality of histamine metabolism. Eosinophil rash is a transient exanthem commonly seen during the first 4 days of life, which usually passes through stages of erythema, papules, and finally pustules; the latter contain large numbers of eosinophils. There is no evidence that it is infective in origin (Finlay and Bound, 1953).

We have, therefore, studied plasma histamine levels in a group of infants with severe pustular eosinophil rashes, and compared them with those in normal unaffected infants.

\section{Material and Methods}

Capillary samples were obtained by free-flowing heel-pricks from 20 healthy babies on each day of the first week of life, with their mothers' permission. Serial samples were not obtained, but individual babies were generally bled more than once. The babies were all bled immediately before their 9 a.m. feeds, and the blood for histamine estimation was centrifuged, separated, and frozen at once. The babies ranged in birthweight from $2600-4300$ g., and in gestational age from 38-42 weeks.

Received December 20, 1968.

* Present address: Department of Paediatrics, Hillingdon Hospital, Middlesex.

† Present address: Department of Child Health, University of Manchester.
Ten babies with marked pustular eosinophil rashes that had appeared on the 2nd to 4th day of life were also bled under the same conditions.

Histamine was assayed fluorimetrically after extraction on a cellulose acid succinate column (Noah and Brand, 1963). An absolute eosinophil count was performed by the method of Dunger (1910), using a modified FuchsRosenthal counting chamber.

\section{Results}

All results are expressed in terms of histamine base.

Table I shows the range of values obtained for each day of the first week of life. Distribution of these values on an arithmetic scale showed a marked skew to the left, and since it is mandatory when comparing groups of figures statistically for the values to be normally distributed, we were compelled to use a logarithmic scale. When the values for the individual days were compared, there were no statistical differences between them, and we therefore pooled the results for the whole of the first week.

Table II expresses the arithmetic conversion of the logarithmic mean and standard deviations for the two groups of babies. The plasma histamine levels of babies with eosinophil rashes are not significantly different from those of normal babies $(p=0 \cdot 25)$, using a one-tailed test. Similarly, the eosinophil count had a logarithmically

TABLE I

Range of Plasma Histamine Levels During the First Week of Life in Infants without Eosinophilic Rash

\begin{tabular}{c|c}
\hline Day of Life & $\begin{array}{c}\text { Range of Plasma Histamine } \\
\text { Concentrations } \\
\text { (ng./ml.) }\end{array}$ \\
\hline 1 & $1 \cdot 7-12 \cdot 0$ \\
2 & $1 \cdot 0-7 \cdot 9$ \\
4 & $1 \cdot 0-10 \cdot 0$ \\
5 & $1 \cdot 1-8 \cdot 5$ \\
6 & $1 \cdot 0-8 \cdot 6$ \\
7 & $1 \cdot 2-6.9$ \\
$1 \cdot 0-6 \cdot 2$ \\
\hline
\end{tabular}


TABLE II

Plasma Histamine Levels for the First Week of Life

\begin{tabular}{l|c|c|c}
\hline & $\begin{array}{c}\text { Arithmetic } \\
\text { Conversion } \\
\text { of Log } \\
\text { Mean } \\
\text { (ng./ml.) }\end{array}$ & $\begin{array}{c}\text { Arithmetic } \\
\text { Conversion } \\
\text { of Log } \\
\text { Mean }+2 \text { SD } \\
\text { (ng./ml.) }\end{array}$ & $\begin{array}{c}\text { Arithmetic } \\
\text { Conversion } \\
\text { of Log } \\
\text { Mean - 2 SD } \\
\text { (ng./ml.) }\end{array}$ \\
\hline $\begin{array}{l}\text { Normal babies(20) } \\
\text { Babies with } \\
\text { eosinophil rash (10) }\end{array}$ & $2 \cdot 8$ & $11 \cdot 2$ & 0.90 \\
\hline
\end{tabular}

normal distribution. The figures for the first week are quoted in Table III because again there was no significant variation from day to day. The babies with eosinophil rashes are included in the same Table; they have a significantly higher count than normal babies $(p=0.001)$.

\section{Discussion}

Free histamine has been shown to be present in increased amounts in the urine of babies severely asphyxiated at birth (Cooper and Davis, 1968). As every birth involves a short period of asphyxia (James, 1960), one might have expected, if urinary free histamine is derived from the plasma, that the plasma levels of histamine might be higher on the first day of life.

However, it has been shown, using ${ }^{14} \mathrm{C}$-labelled histamine, that the clearance of radioactive histamine from the plasma after an intravenous injection is extremely rapid in normal adults (Beall and Vanarsdel, 1960), so the birth process might only produce a very brief rise in the plasma level, which would not be demonstrable by the protocol employed in this study.

The whole blood level of histamine has been shown to be directly proportional to the basophil and eosinophil counts (Code and Mitchell, 1957), but the histamine carried in these cells is bound within the granules and is therefore physiologically inactive.

In looking for a patho-physiological role for histamine in the newborn infant, it seems more valuable to measure free histamine in the plasma. This has only recently become possible with the development of more sensitive and precise assay methods. We found, not unexpectedly, that the plasma histamine concentration and the eosinophil count were not directly related (correlation coefficient $r=0.025 \mathrm{p}=0.1$ ).

There is little published work on the eosinophil count in newborn babies with eosinophil rashes. In our group it is of interest that the count was higher than normal. This was also shown by
TABLE III

Eosinophil Counts for the First Week of Life

\begin{tabular}{ll|c|c|c}
\hline & $\begin{array}{c}\text { Arithmetic } \\
\text { Conversion } \\
\text { of Log. } \\
\text { Mean }\end{array}$ & $\begin{array}{c}\text { Arithmetic } \\
\text { Conversion } \\
\text { of Log. } \\
\text { Mean }+2 \text { SD }\end{array}$ & $\begin{array}{c}\text { Arithmetic } \\
\text { Conversion } \\
\text { of Log. } \\
\text { Mean }-2 \text { SD }\end{array}$ \\
\hline $\begin{array}{l}\text { Normal babies (20) } \\
\begin{array}{l}\text { Babies with eosino- } \\
\text { phil rash (10) }\end{array}\end{array}$ & $\ldots$ & $117 /$ cu.mm. & $630 /$ cu.mm. & $22 \cdot 0 /$ cu.mm. \\
\hline
\end{tabular}

Harris and Schick (1956) to be the case in babies with undifferentiated pustular rashes, many of which were probably eosinophilic. The aetiology of eosinophil rash is unknown, but it has been shown to occur but rarely in premature babies (Carr et al., 1966), whose eosinophil counts are generally low (Burrell, 1953). This suggests that premature babies may be less able to counteract the effects of histamine released during asphyxia than term infants, and might in fact explain their increased liability to develop respiratory distress following asphyxia at birth (Davis, 1966; Reynolds et al., 1965).

\section{Summary}

Values for plasma levels of histamine in healthy newborn infants are presented. There is no significant correlation between the plasma histamine levels and the eosinophil count during this period of life. Newborn babies with pustular eosinophil rashes have normal plasma histamine levels though their eosinophil counts are raised.

We are grateful to the Worshipful Company of Clothworkers for a grant to D.R.H. and to the Sir William Coxen Trust Fund for Laboratory facilities; to Professor J. P. M. Tizard for his advice and criticism; and to Sister Cottrell and Sister Gillard for their help.

\section{REFERENCES}

Archer, R. K. (1963). The Eosinophil Leucocytes. Blackwell, Oxford.

Beall, G. N., and Vanarsdel, P. P., Jr. (1960). Histamine metabolism in human disease. F. clin. Invest., 39, 676.

Burrell, J. M. (1953). A comparative study of the circulating eosinophil level in babies. Part II: In full-term infants. Arch. Dis. Childh., 28, 140.

Carr, J. A., Hodgman, J. E., Freedman, R. I., and Levan, N. E. (1966). Relationship between toxic erythema and infant maturity. Amer. F. Dis. Child., 112, 129.

Code, C. F., and Mitchell, R. G. (1957). Histamine, eosinophils and basophils in the blood. $f$. Physiol. (Lond.), 136, 449.

Cooper, L. V., and Davis, J. A. (1968). Urinary excretion of free histamine in the newborn infant. Lancet, $2,143$.

Davis, J. A. (1966). Respiratory problems of the new-born infant. Postgrad. med. F., 42, 386. 
Dunger, R. (1910). Eine einfache Methode der Zählung der eosinophilen Leukozyten und der praktische Wert dieser Untersuchung. Münch. med. Wschr., 57, 1942.

Finlay, H. V. L., and Bound, J. P. (1953). Utricaria neonatorum (erythema toxicum neonatorum). Arch. Dis. Childh., 28, 404.

Graham H. T., Lowry, O. H., Wheelwright, F., Lenz, M. A., and Parish, H. H., Jr. (1955). Distribution of histamine amongst leucocytes and platelets. Blood, 10, 467.

Harris, J. R., and Schick, B. (1956). Erythema neonatorum. Amer. 7. Dis. Child., 92, 27.

James, L. S. (1960). The effect of pain relief for labor and delivery on the fetus and newborn. Anesthesiology, 21, 405.

Mitchell, R. G., and Cass, R. (1959). Histamine and 5-HT in the blood of infants and children. $\mathcal{F}$. clin. Invest., 38, 595 .
Noah, J. W., and Brand, A. (1963). Simplified micromethod for measuring histamine in human plasma. f. Lab. clin. Med., 62, 506.

Reynolds, E. O. R., Jacobson, H. N., Motoyama, E. K., Kikkawa, Y., Craig, J. M., Orzalesi, M. M., and Cook, C. D. (1965). The effect of immaturity and prenatal asphyxia on the lungs and pulmonary function of newborn lambs: the experimental production of respiratory distress. Pediatrics, $35,382$.

Correspondence to Dr. Lesley V. Cooper, Hammersmith Hospital, Du Cane Road, Lcndon W.12. 